\title{
Stay-green ranking and maturity of corn hybrids: 2. Effects on the performance of lactating dairy cows
}

\author{
K. G. Arriola, S. C. Kim, ${ }^{1}$ C. R. Staples, and A. T. Adesogan ${ }^{2}$ \\ Department of Animal Sciences, Institute of Food and Agricultural Sciences, University of Florida, Gainesville 32608
}

\begin{abstract}
To address producer concerns that feeding high staygreen (SG) corn hybrids is associated with decreased performance and health problems in dairy cows, this study examined how the performance of cows was affected by feeding hybrids with contrasting SG rankings and maturities. Two near-isogenic corn hybrids with high (HSG; Croplan Genetics 691, Croplan Genetics, St. Paul, MN) and low (LSG; Croplan Genetics 737) SG rankings were grown on separate halves of a 10-ha field, harvested at $27 \%$ (maturity 1 ) or $35 \%$ (maturity 2) dry matter (DM) and ensiled in bag silos for 84 and $77 \mathrm{~d}$, respectively. A further treatment involved addition of water $(15 \mathrm{~L} / \mathrm{t})$ to the HSG maturity 1 hybrid during packing to compound the potential negative effects of excess water in the HSG hybrid. Each of the resulting silages was included in a total mixed ration consisting of 35,55 , and $10 \%$ (DM basis) of corn silage, concentrate, and alfalfa hay, respectively. In experiment 1 , the total mixed ration was fed for ad libitum consumption twice daily to 30 Holstein cows $(92 \pm 18 \mathrm{~d}$ in milk). This experiment had a completely randomized design and consisted of two 28-d periods, each with $14 \mathrm{~d}$ for adaptation and $14 \mathrm{~d}$ for sample collection. In experiment 2 , the ruminal fermentation of the diets was measured using 5 ruminally cannulated cows on the last day of three 15 -d periods. Ruminal contraction rate $(2.28 \pm$ 0.14 contractions $/ \mathrm{min})$, milk yield $(36.7 \pm 1.3 \mathrm{~kg} / \mathrm{d})$, yield of milk protein $(1.1 \pm 0.03 \mathrm{~kg} / \mathrm{d})$, and concentration of milk protein $(2.9 \pm 0.03 \%)$ were not affected by treatment. Feeding diets containing HSG instead of LSG reduced intake of crude protein (CP) and neutral detergent fiber, digestibility of neutral detergent fiber, and concentrations of ruminal total volatile fatty acids (VFA) and milk fat when the hybrids were harvested at $27 \%$ DM but not $35 \%$ DM. Across maturity stages, feeding diets containing HSG instead of LSG decreased

Received May 10, 2011.

Accepted September 19, 2011.

${ }^{1}$ Current address: Department of Animal Science, Institute of Agriculture and Life Sciences, Gyeongsang National University, Jinju 660-701, South Korea.

${ }^{2}$ Corresponding author: adesogan@ufl.edu
\end{abstract}

DM and CP digestibility, increased rectal temperature and plasma ceruloplasmin concentration, and increased the efficiency of milk production. Except for increasing yeast and mold counts, adding water to the HSG hybrid harvested at $27 \% \mathrm{DM}$ did not have adverse effects but was associated with greater starch intake, CP digestibility, and ruminal total VFA concentration, and decreased acetate to propionate ratio in dairy cows.

Key words: stay-green, corn, dairy cow, maturity

\section{INTRODUCTION}

Dairy producers in Georgia and Florida have been concerned that feeding corn silage hybrids with high stay-green (SG) rankings has led to increased incidence of digestive upsets, variable manure syndrome, and hemorrhagic bowel syndrome in their cattle in recent years. The SG characteristic typically occurs in corn hybrids with delayed leaf senescence due to partial or complete inhibition of deconstruction of the photosynthetic apparatus during leaf senescence (Thomas and Howarth, 2000). Consequently, the stalk and leaves (stover) remain green, whereas the cob and kernels dry down more rapidly compared with conventional hybrids. The SG phenotype is particularly attractive to corn grain growers because it is associated with increased resistance to diseases (Rosenow, 1984) and lodging (Henzell et al., 1984; Woodfin et al., 1988), thus facilitating grain harvest. However, this phenotype results in lower whole-plant DM concentrations in SG compared with conventional hybrids because of a higher proportion of green leaf (Havilah and Kaiser, 1994). Asynchronous maturity and dry-down rates in the ear and stover of high SG hybrids result in wetter stalks and more mature kernels than in non-SG hybrids. Consequently, the traditional relationship between whole-plant silage moisture concentration and kernel milk line harvest index no longer holds (Lauer, 1998). This may explain why increased seepage from silos has been reported when kernel milk line is used as a decision-making guideline for harvesting SG corn hybrids destined for silage (Lauer, 1998). The SG characteristic may influence the prediction of corn harvest dates with the kernel milk line because kernels get very 
mature while the whole-plant DM remains under $30 \%$ (Thomas, 2001). Anecdotal links between SG ranking of hybrids and digestive upsets or hemorrhagic bowel syndrome in dairy cows have been based on the following theories. First, the greater moisture concentration of high SG hybrids harvested at traditional maturity stages for silage hybrids could worsen the fermentation and predispose stored forage to growth of undesirable organisms such as Clostridia that prefer moist ensiling conditions (Muck and Kung, 2007). Second, in addition to increasing kernel hardness, delaying harvest of SG hybrids to allow the plant to dry could make it more difficult to pack the forage in silos adequately, thus increasing porosity and facilitating the growth of spoilage organisms such as Aspergillus fumigatus, which is thought to trigger hemorrhagic bowel syndrome in dairy cows (Puntenney et al., 2003). The validity of these theories is unknown. Therefore, the aim of this study was to determine the effects of corn hybrid SG ranking and maturity on the performance of dairy cows. A second objective was to determine if addition of water at ensiling to immature hybrids would compound any adverse effects of high SG hybrids on the performance of dairy cows.

\section{MATERIALS AND METHODS}

\section{Forages}

Near-isogenic corn hybrids (relative maturity of 118 d) with high (Croplan Genetics 691) or low SG (Croplan Genetics 737, Croplan Genetics, St. Paul, MN) rankings were grown side by side on a 10-ha field at the Dairy Unit of the University of Florida. Both hybrids were harvested at DM concentrations of $27 \%$ (maturity 1) or $35 \%$ (maturity 2) with a self-propelled harvester (Claas Jaguar 850, Claas of America Inc., Omaha, NE), set at a theoretical length of cut of $1.9 \mathrm{~cm}$, and packed without kernel processing into pressed bag silos with a Versa Bagger (model ID 1012, Versa Corp., Astoria, OR). A further treatment involved spraying water at a rate of $15 \mathrm{~L} / \mathrm{t}$ of silage to the high SG maturity 1 hybrid during packing to increase its moisture content and to simulate effects of wetness on high SG hybrids. This treatment was included to test the theory that if less-mature HSG forages were ensiled while they were still wet due to earlier rainfall or morning dew, the additional water would adversely affect the fermentation of the silage, as suggested previously (Kim and Adesogan, 2006). The forages were ensiled without inoculation or additive treatment for $84 \mathrm{~d}$ (maturity 1) and $77 \mathrm{~d}$ (maturity 2) before the bags were opened.

\section{Cows and Management}

Two experiments were carried out at the Dairy Research Unit of the University of Florida. In experiment
1, 30 Holstein primiparous $(\mathrm{n}=6)$ and multiparous $(\mathrm{n}=24)$ cows in mid lactation $(92 \pm 18$ DIM) weighing $614 \pm 72 \mathrm{~kg}$ and producing $35 \pm 8.2 \mathrm{~kg}$ of milk/d were stratified by milk yield and DIM and allocated randomly to 5 dietary treatments for two 28 -d periods. At the end of period 1, cows were assigned to another treatment such that no cow received the same treatment as in period 1. Each period consisted of $14 \mathrm{~d}$ for adaptation to a new diet and $14 \mathrm{~d}$ for sample collection. Cows were housed in a freestall, open-sided barn fitted with continuously operated misters and fans. Drinking water was constantly available in ad libitum amounts. Freestalls were bedded with sand and at least 1 freestall per cow was available. In experiment 2, 5 multiparous, ruminally fistulated lactating cows weighing $725 \pm 120$ $\mathrm{kg}(411 \pm 175 \mathrm{DIM})$ and producing $14 \pm 6 \mathrm{~kg} / \mathrm{d}$ of milk were used to evaluate the effect of the dietary treatments on $\mathrm{pH}$, VFA, and ammonia- $\mathrm{N}$ concentration in ruminal fluid during 3 consecutive 15 -d periods. Each period consisted of $14 \mathrm{~d}$ of adaptation and $1 \mathrm{~d}$ of ruminal fluid collection. Care of animals used in this study followed protocols approved by the University of Florida Institutional Animal Care and Use Committee.

For both experiments, the TMR contained corn silage, alfalfa hay, and concentrate mixed at 35, 10, and $55 \%$ of dietary DM, respectively (Table 1). All diets were balanced to meet the nutrient requirements of a dairy cow in mid lactation weighing $650 \mathrm{~kg}$, producing $42 \mathrm{~kg} / \mathrm{d}$ of milk (3.6\% fat), with a DMI of $25 \mathrm{~kg} / \mathrm{d}$ (NRC, 2001). The dietary treatments evaluated were as follows: (1) low SG hybrid (LSG) harvested at $27 \%$ of DM, (2) high SG hybrid (HSG) harvested at $27 \%$ of DM, (3) HSG harvested at 35\% of DM, (4) LSG harvested at $35 \%$ of DM, and (5) HSG harvested at $27 \%$ of DM and irrigated (HSG-wet). Cows were fed for ad libitum consumption individually twice daily at 0700 and $1330 \mathrm{~h}$ using Calan gates (American Calan Inc., Northwood, NH). Feed refusals were collected daily at $0600 \mathrm{~h}$. Cows were trained to use Calan gates for 10 $\mathrm{d}$ before the beginning of the trial. Diets were mixed before feeding using Calan Data Rangers (American Calan Inc.).

\section{Sample Collection and Analysis}

Two representative samples of the concentrate and each forage were collected during each week of each collection period in experiment 1 . Subsamples were dried at $60^{\circ} \mathrm{C}$ for $48 \mathrm{~h}$ in a forced draft oven and ground to pass a 1-mm screen using a Wiley mill (Arthur H. Thomas Company, Philadelphia, PA). Concentration of $\mathrm{N}$ was determined by rapid combustion using Macro elemental $\mathrm{N}$ analyzer (Elementar, Hanau, Germany) and $\mathrm{CP}$ was calculated as $\mathrm{N} \times 6.25$. The NDF and ADF concentra- 
Table 1. Ingredient and chemical composition of the diets

\begin{tabular}{|c|c|c|c|c|c|c|}
\hline Item & $\%$ of $\mathrm{DM}$ & & & & & \\
\hline \multicolumn{7}{|l|}{ Ingredient } \\
\hline Corn silage & 35.0 & & & & & \\
\hline Alfalfa hay & 10.0 & & & & & \\
\hline Cottonseed meal & 4.4 & & & & & \\
\hline Citrus pulp & 4.8 & & & & & \\
\hline Cottonseed hulls & 4.7 & & & & & \\
\hline Soy Plus ${ }^{1}$ & 4.2 & & & & & \\
\hline Corn meal & 17.3 & & & & & \\
\hline Soybean meal ( $48 \%$ CP as fed) & 4.2 & & & & & \\
\hline Whole cottonseed & 9.2 & & & & & \\
\hline Liquid molasses & 2.8 & & & & & \\
\hline \multirow[t]{2}{*}{ Mineral mix ${ }^{2}$} & 3.4 & & & & & \\
\hline & \multicolumn{3}{|c|}{ Maturity 1} & \multicolumn{2}{|c|}{ Maturity 2} & \\
\hline Chemical composition $^{3}$ & LSG & HSG & HSG-wet & LSG & HSG & $\mathrm{SE}$ \\
\hline DM, \% & 51.5 & 51.0 & 50.0 & 59.7 & 59.7 & 0.14 \\
\hline Starch, \% of DM & 22.5 & 23.1 & 24.0 & 24.9 & 24.0 & 0.09 \\
\hline $\mathrm{CP}, \%$ of $\mathrm{DM}$ & 18.7 & 18.7 & 18.6 & 18.5 & 18.6 & 0.01 \\
\hline $\mathrm{NDF}, \%$ of DM & 32.2 & 31.9 & 30.8 & 30.3 & 30.7 & 0.09 \\
\hline $\mathrm{ADF}, \%$ of DM & 21.1 & 21.2 & 20.4 & 19.9 & 20.1 & 0.07 \\
\hline $\mathrm{NE}_{\mathrm{L}}, \mathrm{Mcal} / \mathrm{kg}$ & 1.50 & 1.55 & 1.54 & 1.58 & 1.57 & \\
\hline
\end{tabular}

${ }^{1}$ West Central Soy (Ralston, IA).

${ }^{2}$ Mineral mix contained $24.75 \% \mathrm{CP}, 9.9 \% \mathrm{Ca}, 1.1 \% \mathrm{P}, 7.15 \% \mathrm{~K}, 2.75 \% \mathrm{Mg}, 8.25 \% \mathrm{Na}, 1,448 \mathrm{mg} / \mathrm{kg}$ of Mn, 445 $\mathrm{mg} / \mathrm{kg}$ of $\mathrm{Cu}, 1,552 \mathrm{mg} / \mathrm{kg}$ of Zn, $8.54 \mathrm{mg} / \mathrm{kg}$ of Se, $15.5 \mathrm{mg} / \mathrm{kg}$ of I, $147,756 \mathrm{IU}$ of vitamin A/kg, and $717 \mathrm{IU}$ of vitamin $\mathrm{E} / \mathrm{kg}$ (DM basis).

${ }^{3}$ Maturity $1=27 \%$ DM at harvest; maturity $2=35 \%$ DM at harvest; LSG $=$ low stay-green hybrid; HSG $=$ high stay-green hybrid; HSG-wet = HSG hybrid wetted with $15 \mathrm{~L}$ of water $/ \mathrm{t}$ of forage at ensiling.

tions were determined using an Ankom Fiber Analyzer (Ankom Technology, Macedon, NY) as outlined by Van Soest et al. (1991). Heat-stable amylase and sodium sulfite were used for NDF analysis. Starch was determined using the procedure of Holm et al. (1986). In addition, each corn silage was analyzed for yeast and mold counts, aerobic stability, $\mathrm{pH}$, ammonia-N, lactic acid, and VFA. Yeasts and molds were enumerated by spread plating on malt extract agar and incubating for $5 \mathrm{~d}$ at $25^{\circ} \mathrm{C}$. Aerobic stability was measured by placing thermocouple wires at the center of a bag containing 1 $\mathrm{kg}$ of silage within an open-top polystyrene box. The silages were covered with 2 layers of cheesecloth to prevent drying. The thermocouple wires were connected to data loggers (Campbell Scientific Inc., North Logan, UT) that recorded silage and ambient temperature every $30 \mathrm{~min}$ for $5 \mathrm{~d}$. Aerobic stability was denoted by the time that elapsed before a $2^{\circ} \mathrm{C}$ increase in silage temperature above ambient temperature $\left(23^{\circ} \mathrm{C}\right)$. Silage fluid was obtained by blending $20 \mathrm{~g}$ of silage with 200 $\mathrm{mL}$ of distilled water for $30 \mathrm{~s}$ and filtering the slurry through 2 layers of cheesecloth. The $\mathrm{pH}$ was measured at opening and after the 5-d aerobic exposure period with a $\mathrm{pH}$ meter (Accumet, model HP-71, Fisher Scientific, Pittsburgh, PA). The filtrate was centrifuged at $4^{\circ} \mathrm{C}$ and $21,500 \times g$ for 20 min and the supernatant was frozen $\left(-20^{\circ} \mathrm{C}\right)$ in $20-\mathrm{mL}$ vials for subsequent analysis of VFA and ammonia-N. Organic acids were measured using the method of Muck and Dickerson (1988) and an HPLC system (FL 7485, Hitachi, Tokyo, Japan) coupled to a UV detector (Spectroflow 757, ABI Analytical Kratos Division, Ramsey, NJ) set at $210 \mathrm{~nm}$. Ammonia-N was determined using an adaptation for the Technicon auto analyzer (Technicon, Tarrytown, NY) of the Noel and Hambleton (1976) procedure. The anthrone reaction assay (Ministry of Agriculture, Fisheries and Food, 1986) was used to quantify water-soluble carbohydrates (WSC) of corn silages. Hardness of corn kernels separated from the fresh forage was measured by examining the force required to rupture maturity 2 kernels using the Instron Universal Testing Machine (model 5566, Instron, Ithaca, NY) as described by Rich and Teixeira (2005).

Cows were milked daily at 0200, 1000, and $1800 \mathrm{~h}$, and milk yield was measured at each milking for the last $14 \mathrm{~d}$ of each period. Milk samples were collected from 2 consecutive milkings on $2 \mathrm{~d}$ during each week in the last $14 \mathrm{~d}$ of each period, preserved with potassium dichromate, and stored at $4^{\circ} \mathrm{C}$ for milk composition analysis. Wiggans (1986) showed that milk samples collected from 2 consecutive milkings adequately represented milk production by cows milked 3 times a day. Milk 
samples were analyzed by the Southeast Milk Laboratory (Belleview, FL) for concentrations of fat, true protein, and SCC using a Bentley 2000 Near Infrared Reflectance Spectrophotometer (Bentley Instruments Inc., Chaska, MN). Feed efficiency was calculated as kilograms of 3.5\% FCM per kilogram of DMI. Somatic cell scores were generated as described by Norman et al. (2000) for statistical analysis of SCC.

Body weight and BCS were measured for 3 consecutive days after the $1000 \mathrm{~h}$ milking at the beginning and end of each period. Rectal temperature and the number of ruminal contractions in 2-min periods were measured at $1900 \mathrm{~h}$ on the last $5 \mathrm{~d}$ of each period. Feces was scored using a 1 to 4 scale (where $1=$ dry and hard; 2 $=$ soft and firm, forms piles; $3=$ loose and splatters; $4=$ liquid and runny diarrhea) by the same trained observer on the last $5 \mathrm{~d}$ of each period.

A blood sample $(10 \mathrm{~mL})$ was collected at $0900 \mathrm{~h}$ from each cow using Vacutainers (Becton Dickinson, Franklin Lakes, NJ) containing sodium heparin by caudal arteriovenipuncture on the last day of each period. Samples were centrifuged at $2,500 \times g$ for $20 \mathrm{~min}$, and the plasma was frozen at $-20^{\circ} \mathrm{C}$. Concentration of plasma glucose was determined using a Technicon Autoanalyzer II (Bran-Luebbe, Elinsford, NY) and a method modified from Gochman and Schmidz (1972). Plasma urea nitrogen was determined using an autoanalyzer method (Industrial method \# 339-01; Technicon, Tarrytown, NY), which is a modification of the carbamido-diacetyl reaction, described by Coulombe and Favreau (1963). Plasma haptoglobin concentration was determined by measuring haptoglobin/hemoglobin complexing (Makimura and Suzuki, 1982) and ceruloplasmin oxidase activity was measured by using colorimetric procedures described by Demetriou et al. (1974). Plasma concentration of BHBA was determined using the procedure described by Williamson et al. (1962). Aspergillus fumigatus DNA in plasma samples was measured at OmniGen Research LLC (Corvallis, OR) using the real-time, quantitative PCR method described by Wang (2004). Chromic oxide $\left(\mathrm{Cr}_{2} \mathrm{O}_{3}\right)$ was used as an external marker for determination of apparent digestibility. Chromic oxide powder (Fisher Scientific, Fairlawn, NJ) was weighed into gelatin capsules (Jorgensen Laboratories, Loveland, CO) and dosed twice daily with a balling gun $(10 \mathrm{~g} /$ dose at 0700 and $1900 \mathrm{~h})$ for 10 consecutive days in each experimental period. Ten fecal samples (approximately $150 \mathrm{~g}$ ) were collected at 0700 and $1900 \mathrm{~h}$ during the last $5 \mathrm{~d}$ of each period at the time of dosing. Feces were dried to constant weight at $60^{\circ} \mathrm{C}$ in a convection oven and ground to pass through a 1-mm screen in a Wiley mill. A composite sample was made from all 10 fecal samples per cow per period.
Chromium concentration in feces was determined using a Perkin Elmer 5000 Atomic Absorption Spectrometer (Wellesley, MA), according to the procedure described by Williams et al. (1962). Apparent digestibility of DM, $\mathrm{CP}$, and NDF were calculated by the marker ratio technique (Schneider and Flatt, 1975).

Ruminal fluid was collected $(200 \mathrm{~mL})$ from cows in experiment 2 by aspiration and filtered through 2 layers of cheesecloth at $0,2,4,6,8,10$, and $12 \mathrm{~h}$ after feeding on $\mathrm{d} 15$ of each period. The $\mathrm{pH}$ was measured using a pH meter (Accumet model HP-71, Fisher Scientific). The ruminal fluid was acidified with $3 \mathrm{~mL} / \mathrm{sample}$ of $\mathrm{H}_{2} \mathrm{SO}_{4}(50 \% \mathrm{vol} / \mathrm{vol})$. Samples were centrifuged at $12,000 \times g$ for $20 \mathrm{~min}$, after which the supernatant was collected and frozen $\left(-20^{\circ} \mathrm{C}\right)$ in $20-\mathrm{mL}$ vials. Volatile fatty acids were measured using the method of Muck and Dickerson (1988) and an HPLC (model FL 7485, Hitachi) coupled to a UV detector (Spectroflow 757, ABI Analytical Kratos Division) set at $210 \mathrm{~nm}$. The column was a Bio-Rad Aminex HPX-87H (Bio-Rad Laboratories, Hercules, CA) with $0.015 M$ sulfuric acid mobile phase and a flow rate of $0.7 \mathrm{~mL} / \mathrm{min}$ at $45^{\circ} \mathrm{C}$. Ammonia $\mathrm{N}$ was determined with a Technicon Autoanalyzer (Technicon) and an adaptation of the Noel and Hambleton (1976) procedure.

\section{Statistical Analysis}

Both experiments were completely randomized designs and the data were analyzed with the Mixed procedure of SAS (SAS Inst. Inc., Cary, NC). The model used for analyzing the results from experiment 1 was as follows:

$$
\mathrm{Y}_{\mathrm{ijk}}=\mu+\mathrm{T}_{\mathrm{i}}+\mathrm{P}_{\mathrm{j}}+\mathrm{M}_{\mathrm{k}}+\mathrm{TM}_{\mathrm{ik}}+\mathrm{C}_{\mathrm{l}}+\mathrm{E}_{\mathrm{ijk} \mathrm{k}},
$$

where $Y_{\mathrm{ijk}}=$ dependent variable, $\mu=$ general mean, $\mathrm{T}_{\mathrm{i}}=$ treatment effect (fixed effect), $\mathrm{P}_{\mathrm{j}}=$ period effect (fixed), $\mathrm{M}_{\mathrm{k}}=$ maturity effect, $\mathrm{TM}_{\mathrm{ik}}=$ treatment $\times$ maturity interaction, $\mathrm{C}_{1}=$ cow effect (random effect), and $\mathrm{E}_{\mathrm{ijkl}}=$ experimental error.

The model used for analyzing rectal temperature and feces score in experiment 1 , and ruminal $\mathrm{pH}, \mathrm{VFA}$, and ammonia- $\mathrm{N}$ data in experiment 2 was as follows:

$$
\mathrm{Y}_{\mathrm{ijk}}=\mu+\mathrm{T}_{\mathrm{i}}+\mathrm{M}_{\mathrm{j}}+\mathrm{TM}_{\mathrm{ij}}+\mathrm{P}_{\mathrm{k}}+\mathrm{H}_{\mathrm{l}}+\mathrm{C}_{\mathrm{m}}+\mathrm{E}_{\mathrm{ijklm}} \text {, }
$$

where $Y_{\mathrm{ijk}}=$ dependent variable, $\mu=$ general mean, $\mathrm{T}_{\mathrm{i}}$ = treatment effect (fixed effect), $\mathrm{M}_{\mathrm{j}}=$ maturity effect, $\mathrm{TM}_{\mathrm{ij}}=$ treatment $\times$ maturity interaction, $\mathrm{P}_{\mathrm{k}}=$ period effect (fixed), $\mathrm{H}_{1}=$ time effect (repeated measurement), $\mathrm{C}_{\mathrm{m}}=$ cow effect (random effect), and $\mathrm{E}_{\mathrm{ijklm}}=$ experimental error. 
Table 2. Chemical composition of corn forages and silages differing in maturity, stay-green ranking, and water treatment at ensiling $(\mathrm{n}=4)^{1}$

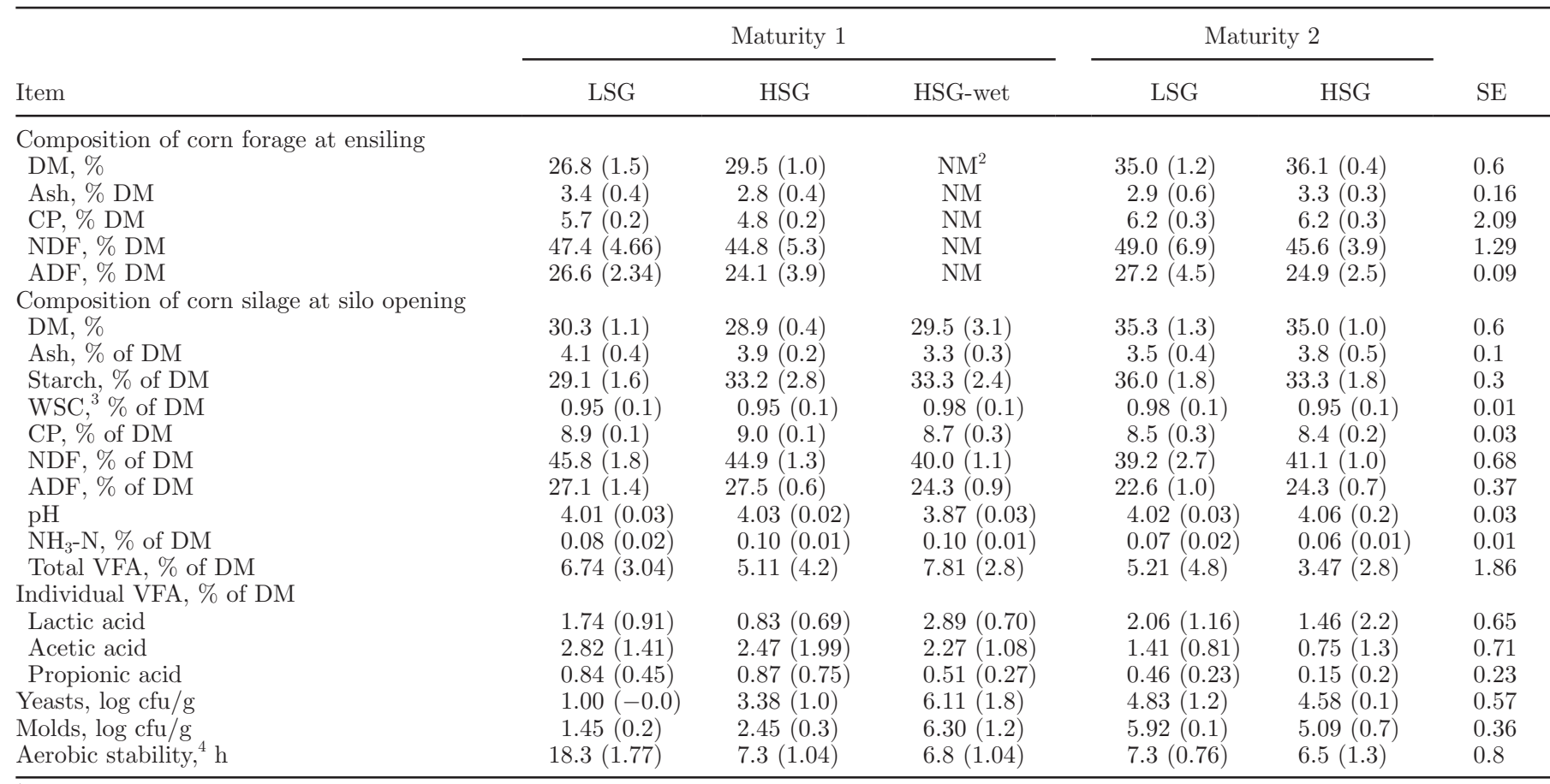

${ }^{1}$ Maturity $1=27 \%$ DM at harvest; maturity $2=35 \%$ DM at harvest; LSG = low stay-green hybrid; HSG = high stay-green hybrid; HSG-wet $=$ HSG hybrid wetted with $15 \mathrm{~L}$ of water/t of forage at ensiling.

${ }^{2} \mathrm{NM}=$ not measured because the forage was sprayed with water as it was being packed into the bags for storage.

${ }^{3} \mathrm{WSC}=$ water-soluble carbohydrate.

${ }^{4}$ Aerobic stability $=$ time before silage temperature exceeded ambient temperature by $>2{ }^{\circ} \mathrm{C}$.

The covariance structure used was autoregressive order $1[\operatorname{AR}(1)]$, and a slice statement was used to detect differences among treatments at each incubation time. Significance was declared at $P<0.05$ and tendencies at $P>0.05 \leq 0.10$. For both experiments, contrasts were used to examine effects of SG, maturity, and water addition (HSG vs. HSG-wet at maturity 1).

\section{RESULTS AND DISCUSSION}

\section{Chemical Composition of Corn Silage}

The chemical compositions of the forages and the silages (Table 2) were typical of corn forages and silages made in the southeastern United States (Huisden et al., 2009; Kang et al., 2009), except that propionic acid concentrations were inexplicably higher than normal. On average, maturity 1 forages and silages had more NDF and ADF than maturity 2 forages and silages, respectively, whereas starch concentrations increased with maturity. Others have reported that starch concentration increases and fiber concentration decreases with increasing maturity of corn hybrids (Harrison et al., 1996; Bal et al., 1997). Starch concentration increased with maturity in LSG hybrids but not HSG hybrids, possibly reflecting the faster kernel maturation rate of the latter (Thomas and Smart, 1993). The higher SG ranking was associated with lower total VFA, lactic acid, and acetic acid concentrations. In addition, higher SG resulted in less propionic acid at maturity 2 and greater ammonia- $\mathrm{N}$ concentrations at maturity 1. These changes are due in part to the reduction in water-soluble carbohydrates and lower water activity in drier forages.

Yeast and mold counts increased with maturity as reported in the companion article (Arriola et al., 2012). Yeast and mold counts were higher for HSG than LSG hybrids at maturity 1 but not at maturity 2; therefore, aerobic stability was shorter for HSG than LSG hybrids at maturity 1. Fungal counts may increase with maturity in corn silage because the mature forage is more difficult to pack and the resulting porosity facilitates fungal growth. In addition, lower concentrations of acetic and propionic acids, which are potent antifungal agents (Moon, 1983), in the more mature forage may have contributed to the greater fungal growth with maturity. That the LSG maturity 1 silage was unstable, despite having low yeast and mold counts, is surprising and may reflect initiation of spoilage in this silage by organisms other than yeasts, such as acetic acid bac- 
teria (McDonald et al., 1981), but it is unclear why the latter occurred only in this treatment. This study suggests that higher fungal counts may occur at early maturity stages in hybrids with higher versus lower SG rankings, which could predispose to the shorter aerobic stability of the former. More research is needed to explain these findings and to indicate if they occur in other HSG hybrids.

Addition of water to the HSG maturity 1 hybrid was associated with greater lactic acid concentration and lower concentrations of NDF and ADF, and acetic and propionic acids. These changes suggest that added water increased the activity of fibrolytic bacteria, leading to increased cell wall hydrolysis into sugars that were fermented to lactic acid. More research is needed to validate these suggestions. However, desirable effects of water addition were tempered by the increased fungal counts caused by this treatment.

\section{Voluntary Intake and Apparent Digestibility}

Dry matter intake did not differ with maturity or SG ranking (Table 3). Likewise, DMI in the fistulated cows was unaffected $(P>0.50)$ by treatment $(18.5$, $18.2,17.1,19.2,18.6, \mathrm{SE}=1.90$, for LSG, HSG, and HSG-wet at maturity 1 and LSG and HSG at maturity 2 , respectively). Intake of starch $(P=0.09)$ tended to be lower for cows fed HSG compared with LSG diets. Intakes of $\mathrm{CP}(P=0.07)$ and $\mathrm{NDF}(P=0.05)$ tended to be lower for cows fed HSG compared with LSG diets of maturity 1 because of the numerically lower DMI in cows fed HSG diets $(\mathrm{SG} \times$ maturity interaction). Ettle and Schwarz (2003) reported that corn silage hybrid type had no effect on DMI, but daily intake of crude fiber was greater for a HSG hybrid than for hybrids with synchronous senescence of ear and stover (dry-down hybrids). Zorn et al. (2008) reported that intakes of $\mathrm{DM}, \mathrm{NE}_{\mathrm{L}}$, starch, and NDF were unaffected by feeding HSG versus dry-down hybrids. These different effects of SG on component intake may reflect variations in the types of SG hybrids used in the studies. Thomas and Smart (1993) noted that 4 types of SG exist and stated that the appearance of the SG phenotype could reflect genetic or cosmetic differences among hybrids. Arriola et al. (2012) reported that increasing the SG ranking had contrasting effects on the nutritive value of corn hybrids from different companies. Higher SG rankings were associated with decreased digestibility in hybrids from one company but not in those from a second company; therefore, the authors emphasized the need for more research on differences between SG attributes of hybrids from different sources.

As for the more mature forage in this study, Bal et al. (1997) reported that DMI by dairy cows did not differ when the DM concentration of corn hybrids ranged from 30 to $42 \%$. Phipps et al. (2000) reported that DMI by dairy cows was lower when corn silage was harvested at $39 \%$ DM compared with 26 or $29 \%$ DM. Forouzmand et al. (2005) reported that intakes of DM, $\mathrm{CP}, \mathrm{NDF}$, and ADF were lower when corn silage was harvested at $38 \%$ DM compared with $27 \%$ or $31 \%$ DM. However, Ettle and Schwarz (2003) reported that total DMI and DMI of corn silage harvested at 30 to $32 \%$ DM were lower than those for corn silage harvested at

Table 3. Effect of maturity (MAT) at harvest and water addition to corn silages with contrasting stay-green (SG) rankings on feed intake, apparent digestibility, and energy measures of lactating dairy cows ${ }^{1}$

\begin{tabular}{|c|c|c|c|c|c|c|c|c|c|c|}
\hline Item & \multicolumn{3}{|c|}{ Maturity 1} & \multicolumn{2}{|c|}{ Maturity 2} & $\mathrm{SE}$ & \multicolumn{4}{|c|}{ Effect $(P$-value $)$} \\
\hline $\mathrm{DM}$ & 29.8 & 26.3 & 27.3 & 26.7 & 26.1 & 1.4 & NS & NS & NS & NS \\
\hline Starch & 6.6 & 5.8 & 6.7 & 6.5 & 6.2 & 0.3 & 0.09 & NS & NS & 0.05 \\
\hline $\mathrm{CP}$ & 5.6 & 4.7 & 5.1 & 4.9 & 4.8 & 0.2 & 0.02 & 0.08 & 0.07 & NS \\
\hline $\mathrm{NDF}$ & 9.6 & 8.0 & 8.4 & 8.0 & 7.9 & 0.4 & 0.04 & 0.01 & 0.05 & NS \\
\hline Starch & 98.2 & 98.4 & 98.5 & 98.1 & 97.9 & 0.2 & NS & 0.01 & NS & NS \\
\hline $\mathrm{CP}$ & 70.0 & 64.4 & 67.1 & 70.9 & 66.6 & 1.0 & $<0.001$ & 0.08 & NS & 0.03 \\
\hline NDF & 61.0 & 52.2 & 51.1 & 56.7 & 53.1 & 1.8 & 0.002 & NS & NS & NS \\
\hline \multicolumn{11}{|l|}{ Energy measures, Mcal/d } \\
\hline $\mathrm{NE}_{\mathrm{L}}$ intake & 44.8 & 40.8 & 42.0 & 42.1 & 41.0 & 2.3 & NS & NS & NS & NS \\
\hline Milk energy output & 25.4 & 24.3 & 24.6 & 23.5 & 24.4 & 1.1 & NS & NS & NS & NS \\
\hline Maintenance requirement & 9.9 & 10.0 & 10.0 & 10.0 & 10.0 & 0.2 & NS & NS & NS & NS \\
\hline
\end{tabular}

${ }^{1}$ Maturity $1=27 \%$ DM at harvest; maturity $2=35 \%$ DM at harvest; LSG = low stay-green hybrid; HSG = high stay-green hybrid; HSG-wet $=$ HSG hybrid wetted with $15 \mathrm{~L}$ of water/t of forage at ensiling.

${ }^{2}$ Moist $=$ effect of HSG versus HSG-wet at maturity 1.

$\mathrm{NS}=P>0.15$. 
38 to $42 \%$ DM. These discrepancies in maturity effects on DMI probably reflect variations in growth conditions, maturity at harvest, and hybrid genotypes. It is important to note that no indication was given about whether the hybrids described above exhibited the SG phenotype or had that genotype. Therefore, effects of maturity on DMI in such hybrids are likely to be different from those on hybrids with high SG rankings. This is supported by the significant interactions between $\mathrm{SG}$ and maturity on NDF and CP intake as well as milk fat and some ruminal VFA concentrations in this study.

The HSG diets had lower $(P<0.01) \mathrm{DM}, \mathrm{NDF}$, and CP digestibilities than the LSG diets. Schlagheck et al. (2000) reported that SG hybrids had similar digestibility as dry-down hybrids, but Ettle and Schwarz (2003) reported that OM of dry-down hybrids was more digestible than that of an HSG hybrid. The lower digestibility of HSG compared with LSG hybrids in the current study agrees with the trend for lower digestibility of corn hybrids with higher SG ranking from the same source as that used in this study (Arriola et al., 2012).

Starch digestibility decreased $(P=0.01)$ with maturity; however, DM and $\mathrm{CP}$ digestibility tended to increase $(P=0.08)$, but NDF digestibility was not affected. Ettle and Schwarz (2003) reported that stage of maturity (30 to $32 \% \mathrm{DM}$ and 38 to $42 \% \mathrm{DM}$ ) did not affect OM digestibility. Bal et al. (1997) reported that DM digestibility was similar for cows fed corn silage harvested at 30,32 , and $35 \% \mathrm{DM}$ but that starch digestibility decreased with maturity. Decreases in starch digestibility with increasing plant maturity have been associated with greater kernel hardness, which could increase passage of intact kernels through the rumen and reduce postruminal starch utilization (Harrison et al., 1996). However, the maturity-related difference in starch digestibility in this study is unlikely to be biologically significant.

Adding water to the maturity 1 HSG hybrid increased $(P=0.05)$ starch intake by numerically increasing DMI of HSG-wet without affecting starch concentration of HSG and HSG-wet forages. Adding water resulted in increased CP digestibility $(P=0.03)$, perhaps by optimizing conditions for growth of proteolytic bacteria in the silage (Kim and Adesogan, 2006).

\section{Milk Production and Composition}

Milk and 3.5\% FCM yield, yield and concentration of milk constituents, and energy intake, requirement, and balance measures were mostly unaffected by SG ranking (Tables 3 and 4). A notable exception was that milk fat concentration decreased as SG ranking increased at maturity 1 but not at maturity $2(P=0.04)$. This decrease in milk fat concentration was probably due to the considerably lower intake of digestible NDF (4.2 vs. $5.8 \mathrm{~kg} / \mathrm{d}$ ) of the HSG compared with LSG maturity 1 diets. Body weight gain and the FCM:DMI ratio increased $(P=0.03)$ as SG ranking increased.

Production of FCM $(P=0.06)$ tended to decrease with increasing maturity, probably reflecting lower NDF intake and digestibility as the forages matured. Phipps et al. (2000) reported that cows fed corn silage (non-SG) harvested at 29 to $30 \%$ DM had greater milk yield than cows fed corn silage harvested at 39\% DM. In contrast, Bal et al. (1997) compared the milk production of cows fed diets containing corn silage (non-SG) harvested at $30,32,35$, and $42 \% \mathrm{DM}$ and reported that production was greatest from cows fed the corn silage harvested at 35\% DM and least from those fed corn

Table 4. Effect of maturity (MAT) at harvest and water addition to corn silages with contrasting stay-green (SG) rankings on milk production, milk composition, and feed efficiency of lactating dairy cows ${ }^{1}$

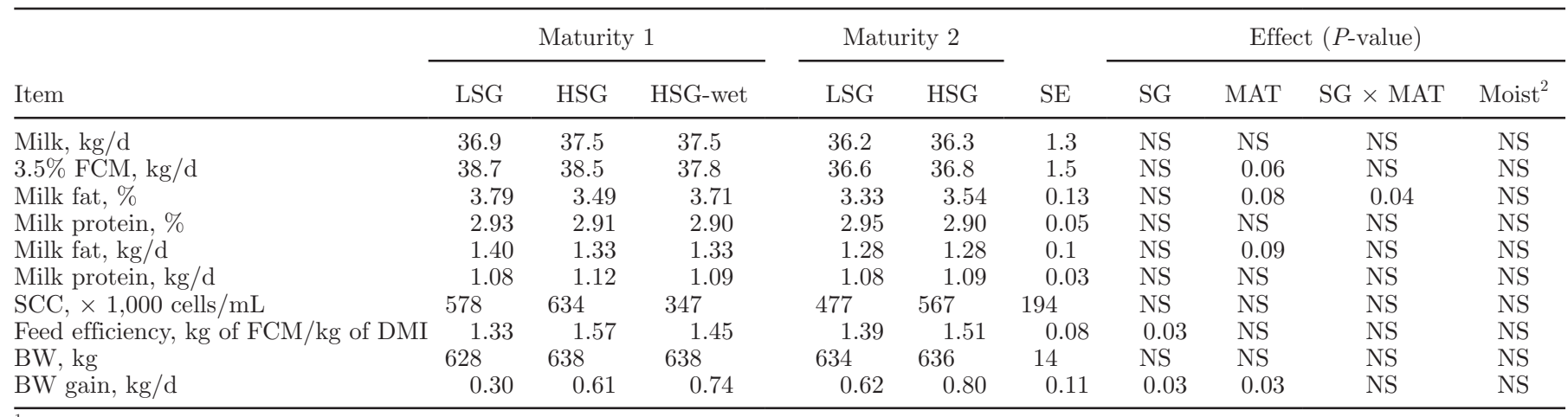

\footnotetext{
${ }^{1}$ Maturity $1=27 \%$ DM at harvest; maturity $2=35 \%$ DM at harvest; LSG = low stay-green hybrid; HSG = high stay-green hybrid; HSG-wet $=$ HSG hybrid wetted with $15 \mathrm{~L}$ of water/t of forage at ensiling.

${ }^{2}$ Moist $=$ effect of HSG versus HSG-wet at maturity 1.

$\mathrm{NS}=P>0.15$.
} 
silage harvested at 30\% DM. In the current study, milk fat yield tended $(P=0.09)$ to decrease with increasing maturity but milk protein yield was unaffected. Similarly, Johnson et al. (2002) reported that milk fat yield was lower for cows fed corn silage harvested at $38.2 \%$ DM compared with 27 and 33\% DM but milk protein concentration and yield were not affected. However, Bal et al. (1997) reported that milk protein production was greater by cows fed corn silage harvested at $35 \%$ DM instead of 30,32 , or $42 \%$ DM because of the greater starch concentration and digestibility in corn silage harvested at $35 \%$ DM.

\section{Health Indices, Blood Metabolites, and Rumen Parameters}

Concentrations of plasma glucose were not affected by $\mathrm{SG}$ ranking but plasma ceruloplasmin concentration increased $(P=0.001)$ with increasing SG ranking, as did rectal temperature $(P=0.03$; Table 5$)$. As an acute phase protein, ceruloplasmin functions as an endogenous modulator of the inflammatory response (Cousins, 1985) and has been used as an indicator of inflammation in various species, including cattle (Arthington et al., 1996). For unknown reasons, ceruloplasmin concentration also increased with maturity but the response was less than half of that attributable to SG ranking. Rectal temperature is an important measure of the acute phase immune response, which is highly correlated to serum concentrations of other acute phase markers, including serum amyloid A, IL-6, and cortisol in cattle (Carroll et al., 2009). That both of these indicators of the acute phase response were greater in cows fed HSG compared with LSG diets indicates that feeding the HSG diet increased inflammatory stress levels in the cows. Aspergillus fumigatus was not detected in the plasma, and rumen contraction rate and fecal score were unaffected by SG ranking. Furthermore, no instances of digestive upsets or diarrhea were recorded.

Plasma haptoglobin concentration decreased $(P=$ $0.01)$ with maturity, whereas concentrations of plasma glucose $(P=0.09)$ and ceruloplasmin $(P=0.01)$ increased. Fecal score increased $(P=0.03)$ with maturity, perhaps because NDF intake decreased and yeast and mold counts of the silages increased with maturity. However, the increase in fecal score was small relative to those indicating metabolic problems in dairy cows.

Ruminal fluid $\mathrm{pH}$ tended to increase $(P=0.09)$ slightly with increasing maturity, whereas acetic acid concentrations decreased $(P<0.001)$, partly due to decreased NDF intake with increasing maturity. Ruminal $\mathrm{NH}_{3}-\mathrm{N}$ concentration $(P=0.008)$ was greater, whereas total VFA concentration $(P<0.001)$ was less in cows fed HSG compared with LSG, and these differences were greater for cows fed maturity 1 silage than for those fed maturity 2 silage $(\mathrm{SG} \times$ maturity interaction, $P=0.06$ and 0.04 , respectively). The lower total VFA concentration from HSG diets reflects their lower digestibility. Lower ruminal energy supply from the HSG compared with the LSG diet may have contributed to the greater ruminal $\mathrm{NH}_{3} \mathrm{~N}$ concentrations from the HSG diets due to less efficient capture of ruminal $\mathrm{NH}_{3}$ for microbial protein synthesis.

Ruminal concentrations of propionic and butyric acid decreased with increasing SG at maturity 1 but increased at maturity $2(\mathrm{SG} \times$ maturity interaction; $P \leq 0.001$ ), whereas contrasting trends were evident for branched-chain VFA $(\mathrm{SG} \times$ maturity interaction; $P \leq 0.01)$. Ruminal fluid acetate:propionate ratio was lower for LSG than HSG at maturity 1 (3.0 vs. 3.2), but this trend was reversed at maturity 2 (3.1 vs. 2.6; $\mathrm{SG} \times$ maturity interaction; $P<0.001)$. Therefore, the efficiency of ruminal fermentation was slightly lower in cows fed HSG hybrids at maturity 1 but was greater in cows fed HSG hybrids at maturity 2. This suggests that HSG hybrids should be harvested at 35\% DM rather than $27 \%$ DM to increase the efficiency of ruminal fermentation. The former approximates the maturity stage $(37 \% \mathrm{DM})$ at which the nutritive value and DM yield of SG hybrids were optimized in the companion study (Arriola et al., 2012).

Adding water to the HSG hybrid reduced concentrations of ruminal ammonia-N $(P=0.03)$, lactic acid $(P$ $=0.02)$, butyric acid $(P=0.09)$, acetate:propionate ratio $(P=0.04)$, increased total VFA concentration $(P<0.01)$, and propionic acid proportion $(P=0.05)$, and tended to reduced butyric acid $(P=0.09)$. Therefore, adding water increased the extent and efficiency of ruminal fermentation. This is probably because the added water stimulated the growth of lactic acid bacteria in silage as suggested by the greater lactic acid concentration of the wetted silage. Passage of silage lactic acid bacteria into the rumen has been associated with increased total VFA concentration and probiotic effects in dairy cows (Weinberg et al., 2003, 2004). In summary, water addition at ensiling increased fungal counts and lactic acid concentration in the silage and had beneficial effects on ruminal fermentation but it did not affect the performance of the cows.

\section{CONCLUSIONS}

Harvesting the HSG hybrid at $27 \%$ DM instead of $35 \%$ DM was associated with less-desirable responses such as decreased intake of $\mathrm{CP}$ and NDF, greater decreases in digestibility of NDF, a less efficient ruminal fermentation, and milk fat depression, suggesting that HSG hybrids should be harvested at 35\% DM. Across 
Table 5. Effect of maturity (MAT) at harvest and water addition to corn silages with contrasting stay-green (SG) rankings on plasma metabolites, health indices, and ruminal fermentation measures of lactating dairy cows

\begin{tabular}{|c|c|c|c|c|c|c|c|c|c|c|}
\hline \multirow[b]{2}{*}{ Item } & \multicolumn{3}{|c|}{ Maturity 1} & \multicolumn{2}{|c|}{ Maturity 2} & \multirow[b]{2}{*}{$\mathrm{SE}$} & \multicolumn{4}{|c|}{ Effects ( $P$-value) } \\
\hline & LSG & HSG & HSG-wet & LSG & HSG & & SG & MAT & $\mathrm{SG} \times \mathrm{MAT}$ & Moist $^{2}$ \\
\hline Plasma urea N, mg/dL & 19.4 & 19.4 & 19.1 & 18.8 & 19.7 & 0.8 & NS & NS & NS & NS \\
\hline Plasma glucose, mg/dL & 64.4 & 66.1 & 66.6 & 66.9 & 66.9 & 1.0 & NS & 0.09 & NS & NS \\
\hline $\mathrm{BHBA}, \mathrm{mg} / \mathrm{dL}$ & 2.61 & 3.07 & 3.04 & 2.78 & 2.74 & 0.27 & NS & NS & NS & NS \\
\hline Ceruloplasmin, mg/dL & 15.9 & 17.9 & 18.1 & 16.9 & 21.4 & 0.9 & 0.001 & 0.01 & NS & NS \\
\hline Haptoglobin $^{3}$ & 3.2 & 1.9 & 1.6 & 1.2 & 1.2 & 0.6 & NS & 0.01 & NS & NS \\
\hline Rectal temperature, ${ }^{\circ} \mathrm{C}$ & 38.06 & 38.11 & 38.00 & 37.89 & 38.17 & 0.08 & 0.03 & NS & NS & NS \\
\hline Rumen contractions, no./min & 2.2 & 2.2 & 2.1 & 2.4 & 2.4 & 0.1 & NS & NS & NS & NS \\
\hline Feces score $^{4}$ & 2.48 & 2.53 & 2.68 & 2.72 & 2.63 & 0.08 & NS & 0.03 & NS & NS \\
\hline \multicolumn{11}{|l|}{ Ruminal fluid } \\
\hline $\mathrm{pH}$ & 5.9 & 6.0 & 6.1 & 6.1 & 6.0 & 0.1 & NS & 0.09 & NS & NS \\
\hline $\mathrm{NH}_{3}-\mathrm{N}, \mathrm{mg} / \mathrm{dL}$ & 19.0 & 27.9 & 21.6 & 19.1 & 20.9 & 2.0 & 0.008 & 0.08 & 0.06 & 0.03 \\
\hline Total VFA, $\mathrm{m} M$ & 99.5 & 67.6 & 112.4 & 75.2 & 67.2 & 5.4 & 0.001 & 0.03 & 0.04 & 0.001 \\
\hline Lactic acid, molar \% & 1.7 & 1.9 & 0.4 & 1.1 & 1.9 & 0.5 & NS & NS & NS & 0.02 \\
\hline Acetic acid, molar \% & 58.1 & 57.8 & 57.6 & 55.8 & 54.1 & 0.6 & NS & 0.001 & NS & NS \\
\hline Propionic acid, molar \% & 19.1 & 18.3 & 19.2 & 18.3 & 20.2 & 1.2 & 0.09 & NS & 0.001 & 0.05 \\
\hline Butyric acid, molar $\%$ & 12.7 & 12.4 & 11.9 & 11.1 & 12.4 & 0.6 & 0.01 & 0.001 & 0.001 & 0.09 \\
\hline Isovaleric acid and 2-methyl butyric acid, molar $\%$ & 3.8 & 4.6 & 4.5 & 5.1 & 4.5 & 0.7 & NS & 0.03 & 0.01 & NS \\
\hline Valeric acid, molar \% & 2.6 & 2.2 & 2.5 & 2.5 & 2.0 & 0.3 & 0.003 & NS & NS & NS \\
\hline Isobutyric acid, molar \% & 3.1 & 3.5 & 3.2 & 4.9 & 3.7 & 0.4 & NS & 0.002 & 0.01 & NS \\
\hline Acetate:propionate & 3.0 & 3.2 & 3.0 & 3.1 & 2.6 & 0.1 & 0.001 & 0.001 & 0.001 & 0.04 \\
\hline
\end{tabular}

${ }^{1}$ Maturity $1=27 \%$ DM at harvest; maturity $2=35 \%$ DM at harvest; LSG = low stay-green hybrid; HSG = high stay-green hybrid; HSG-wet = HSG hybrid wetted with 15 L of

${ }^{2}$ Moist = effect of HSG versus HSG-wet at maturity 1

@ Arbitrary units; spectrophotometer absorbance (optical density) at $450 \mathrm{~nm} \times 100$.

${ }^{4}$ Feces was scored on a 1 to 4 scale: $1=$ dry, $2=$ normal, $3=$ loose, $4=$ diarrhea.

$\stackrel{N}{\gtrless} \mathrm{NS}=P>0.15$. 
maturities, feeding the HSG hybrid instead of the LSG hybrid numerically reduced DMI and statistically reduced digestibility of DM, NDF, and CP, but did not affect yield of milk or 3.5\% FCM. Consequently, the FCM:DMI ratio was increased by feeding the HSG hybrid. However, the HSG silage had greater yeast counts, and the HSG diet was associated with greater rectal temperature and plasma ceruloplasmin concentrations, indicating that it caused greater inflammatory stress. Nevertheless, no direct link between high SG rankings in corn silages and the incidence of disease in dairy cattle was found in this study. Adding water to HSG hybrids increased starch intake, CP digestibility, and ruminal total VFA concentration but also increased silage yeast and mold counts.

\section{ACKNOWLEDGMENTS}

We gratefully acknowledge funding or in-kind contributions for this study from the Southeast Milk Check-Off (Belleview, FL) and Croplan Genetics (St. Paul, MN). We are also grateful to Neil Forsberg (Department of Animal Sciences, Oregon State University, Corvallis) for analysis of Aspergillus fumigatus and to Art Texeira and Ray Bucklin (Department of Agricultural and Biological Engineering, University of Florida, Gainesville) for kernel hardness analysis.

\section{REFERENCES}

Arriola, K. G., S. C. Kim, C. M. Huisden, and A. T. Adesogan. 2012. Stay-green ranking and maturity of corn hybrids: 1. Effects on dry matter yield, nutritional value, fermentation characteristics, and aerobic stability. J. Dairy Sci. 95:964-974.

Arthington, J. D., L. R. Corah, and F. Blecha. 1996. The effect of molybdenum-induced copper deficiency on acute-phase protein proliferation in beef heifers inoculated with bovine herpesvirus-1 concentrations, superoxide dismutase activity, leukocyte numbers, and lymphocyte. J. Anim. Sci. 74:211-217.

Bal, M. A., J. G. Coors, and R. D. Shaver. 1997. Impact of the maturity of corn for use as silage in the diets of dairy cows on intake, digestion, and milk production. J. Dairy Sci. 80:2497-2503.

Carroll, T., H. Raff, and J. W. Findling. 2009. Late-night salivary cortisol for the diagnosis of Cushing syndrome: A meta analysis. Endocr. Pract. 15:335-342.

Coulombe, J. J., and L. Favreau. 1963. A new simple semi micro method for colorimetric determination of urea. Clin. Chem. 9:102-108.

Cousins, R. J. 1985. Absorption, transport, and hepatic metabolism of $\mathrm{Cu}$ and $\mathrm{Zn}$ : Special reference to metallothionein and ceruloplasmin. Physiol. Rev. 65:238-309.

Demetriou, J. A., P. A. Drewes, and J. B. Gin. 1974. Ceruloplasmin. Pages 857-864 in Clinical Chemistry. D. C. Cannon, and J. W. Winkelman, ed. Harper and Row, Hagerstown, MD.

Ettle, T., and F. J. Schwarz. 2003. Effect of maize variety harvested at different maturity stages on feeding value and performance of dairy cows. Anim. Res. 52:337-349.

Forouzmand, M. A., G. R. Ghorbani, and M. Alikhani. 2005. Influence of hybrid and maturity on the nutritional value of corn silage for lactating dairy cows. I: Intake, milk production and component yield. Pakistan J. Nutr. 4:435-441.
Gochman, N., and J. M. Schmidz. 1972. Application of a new peroxide indicator reaction to the specific, automated determination of glucose with glucose oxidase. Clin. Chem. 18:943-950.

Harrison, J. H., L. Johnson, R. Riley, S. Xu, K. Loney, C. W. Hunt and D. Sapienza. 1996. Effect of harvest maturity of whole plant corn silage on milk production and component yield, and passage of corn grain and starch into feces. J. Dairy Sci. 79(Suppl. 1):149. (Abstr.)

Havilah, E. J., and A. G. Kaiser. 1994. The 'stay-green' characteristic and maize silage production. Pages 209-212 in Proc. 2nd Australian Maize Conf. Gatton, Queensland. Australian Institute of Agricultural Science, Curtin, Australia.

Henzell, R. G., R. L. Dodman, A. A. Done, R. L. Brengman, and P. E. Mayers. 1984. Lodging stalk rot, and root rot in sorghum in Australia. Pages 225-235 in Sorghum Root and Stalk Diseases: A Critical Review. L. K. Mughogho, ed. International Crops Research Institute for the Semi-Arid Tropics, Patancheru, India.

Holm, J. I., I. Bjorck, A. Drews, and N. G. Asp. 1986. A rapid method for the analysis of starch. Starch/Die Stärke 7:224-226.

Huisden, C. M., A. T. Adesogan, S. C. Kim, and T. Ososanya. 2009 Effect of applying molasses or inoculants containing homofermentative or heterofermentative bacteria at two rates on the fermentation and aerobic stability of corn silage. J. Dairy Sci. 92:690-697.

Johnson, L. M., J. H. Harrison, D. Davidson, M. Swift, W. C. Mahanna, and K. Shinners. 2002. Corn silage management. II: Effects of hybrid, maturity, and mechanical processing on digestion and energy content. J. Dairy Sci. 85:2913-2927.

Kang, T. W., A. T. Adesogan, S. C. Kim, and S. S. Lee. 2009. Effects of an esterase-producing inoculant on fermentation, aerobic stability, and neutral detergent fiber digestibility of corn silage. J. Dairy Sci. 92:732-738.

Kim, S. C., and A. T. Adesogan. 2006. Influence of ensiling temperature, simulated rainfall, and delayed sealing on fermentation characteristics and aerobic stability of corn silage. J. Dairy Sci. 89:3122-3132.

Lauer, J. 1998. Corn kernel milk stage and silage harvest water. Pages 5-18 in Proc. 1998 Forage Symp. Field Crops 28. University of Wisconsin, Madison.

Makimura, S., and N. Suzuki. 1982. Quantitative determination of bovine serum haptoglobin and its elevation in some inflammatory diseases. Nihon Juigaku Zasshi 44:15-21.

McDonald, P., A. R. Henderson, and S. J. E. Heron. 1991. The Biochemistry of Silage. 2nd ed. Chalcombe Publications, Marlow, UK.

Ministry of Agriculture, Fisheries and Food. 1986. The Analysis of Agricultural Materials. Reference Book 427. MAFF, HMSO, London, UK.

Moon, N. J. 1983. Inhibition of the growth of acid-tolerant yeasts by acetate, lactate, and propionate and their synergistic mixtures. J. Appl. Bacteriol. 55:453-460.

Muck, R. E., and J. T. Dickerson. 1988. Storage temperature effects on proteolysis in alfalfa silage. Trans. ASAE 31:1005-1009.

Muck, R. E., and L. Kung Jr. 2007. Silage production. Pages 617-633 in Forages: The Science of Grassland Agriculture. Vol. II. 6th ed. R. F. Barnes, C. J. Nelson, K. J. Moore, and M. Collins, ed. Blackwell Publishing, Ames, IA.

NRC. 2001. Nutrient Requirements of Dairy Cattle. 7th rev. ed. Natl. Acad. Sci., Washington, DC.

Noel, R. J., and L. G. Hambleton. 1976. Collaborative study of a semiautomated method for determination of crude protein in animal feeds. J. Assoc. Off. Anal. Chem. 59:134-140.

Norman, H. D., R. H. Miller, J. R. Wright, and G. R. Wiggans. 2000. Herd and state means for somatic cell count from dairy herd improvement. J. Dairy Sci. 83:2782-2788.

Phipps, R. H., J. D. Sutton, D. E. Beever, and A. K. Jones. 2000. The effect of crop maturity on the nutritional value of maize silage for lactating dairy cows. 3. Food intake and milk production. J. Anim. Sci. 71:401-409.

Puntenney, S. B., Y. Wang, and N. E. Forsberg. 2003. Mycotic infections in livestock: Recent insights and studies on etiology, diagnostics and prevention of hemorrhagic bowel syndrome. Pages 49-63 
in Southwest Nutrition \& Management Conference, Phoenix, AZ. Department of Animal Science, University of Arizona, Tucson.

Rich, E. C., and A. A. Teixeira. 2005. Physical properties of Mucuna (Velvet) bean. Appl. Eng. Agric. 21:437-443.

Rosenow, D. T. 1984. Breeding for resistance to root and stalk rots in Texas. Pages 209-217 in Sorghum Root and Stalk Rots: A Critical Review. L. K. Mughogho, and G. Rosenberg, ed. International Crops Research Institute for the Semi-Arid Tropics, Patancheru, India.

Schlagheck, A., N. Luetke Entrup, and M. Freitag. 2000. Effect of the ripening character (stay green/ dry down) on the in vitro digestibility of maize genotypes with regard to different parts of the maize plant. Landbauforschung Voelkenrode. Sonderheft. 217:94-101.

Schneider, B. H., and W. P. Flatt. 1975. The indicator method. Page 168 in The Evaluation of Feeds Through Digestibility Experiments. University of Georgia Press, Athens.

Thomas, E. D. 2001. Corn Hybrids for Silage: 2001 Performance and Outlook for 2002. Page 35 in December 2001 issue. NE Dairy Business, East Syracuse, NY.

Thomas, H., and C. J. Howarth. 2000. Five ways to stay green. J. Exp. Bot. 51:329-337.

Thomas, H., and C. M. Smart. 1993. Crops that stay green. Ann. Appl. Biol. 123:193-219.

Van Soest, P. J., J. B. Robertson, and B. A. Lewis. 1991. Methods for dietary fiber, neutral detergent fiber and nonstarch polysaccharides in relation to animal nutrition. J. Dairy Sci. 74:3583-3597.
Wang, Y. Q. 2004. Hemorrhagic bowel syndrome in dairy cattle and efficacy of feed additive in stimulating immune response in livestock. $\mathrm{PhD}$ Diss. Oregon State University, Corvallis.

Weinberg, Z. G., Y. Chen, and M. Gamburg. 2004. The passage of lactic acid bacteria from silage into rumen fluid, in vitro studies. J. Dairy Sci. 87:3386-3397.

Weinberg, Z. G., R. E. Muck, and P. J. Weimer. 2003. The survival of lactic acid bacteria in rumen fluid. J. Appl. Microbiol. 94:10661071.

Wiggans, G. R. 1986. Estimating daily yields of cows milked three times a day. J. Dairy Sci. 69:2935-2940.

Williams, C. H., D. J. David, and O. Iismaa. 1962. The determination of chromic oxide in feces samples by atomic absorption spectrophotometry. J. Agric. Sci. 59:381-385.

Williamson, D. H., J. Mellanby, and H. A. Krebs. 1962. Enzymatic determination of $\mathrm{D}(-)-\beta$-hydroxybutyric acid and acetoacetic acid in blood. Biochem. J. 228:727-733.

Woodfin, C. A., D. T. Rosenow, and L. E. Clark. 1988. Association between the stay-green trait and lodging resistance in sorghum. Page 102 in Agron. Abstr. ASA, Madison. WI.

Zorn, R. L. G., H. A. Schooten, and H. van Laar. 2008. Effect of silage maize hybrid (dry down vs. stay green) on dairy cow performance. Page 876 in Biodiversity and Animal Feed: Future Challenges for Grassland Production. Proc. 22nd Gen. Mtg. Eur. Grassl. Fed. Uppsala, Sweden. 